\title{
Plasma Transthyretin Indicates the Direction of both Nitrogen Balance and Retinoid Status in Health and Disease
}

\author{
Ingenbleek Yves ${ }^{1}$ and Bienvenu Jacques ${ }^{2,3, *}$ \\ ${ }^{1}$ Laboratory of Nutrition, Faculty of Pharmacy, University Louis Pasteur Strasbourg 1, France; ${ }^{2}$ Laboratory of Immu- \\ nology, Hospices Civils de Lyon and ${ }^{3}$ INSERM U 851, University Claude Bernard Lyon 1, France
}

\begin{abstract}
Whatever the nutritional status and the disease condition, the actual transthyretin (TTR) plasma level is determined by opposing influences between anabolic and catabolic alterations. Rising TTR values indicate that synthetic processes prevail over tissue breakdown with a nitrogen balance (NB) turning positive as a result of efficient nutritional support and / or anti-inflammatory therapy. Declining TTR values point to the failure of sustaining NB as an effect of maladjusted dietetic management and / or further worsening of the morbid condition. Serial measurement of TTR thus appears as a dynamic index defining the direction of NB in acute and chronic disorders, serving as a guide to alert the physician on the validity of his therapeutic strategy. The level of TTR production by the liver also works as a limiting factor for the cellular bioavailability of retinol and retinoid derivatives which play major roles in the brain ageing process. Optimal protein nutritional status, as assessed by TTR values within the normal range, prevents the occurrence of vascular and cerebral damages while maintaining the retinoid-mediated memory, cognitive and behavioral activities of elderly persons.
\end{abstract}

\section{INTRODUCTION}

Measurement of transthyretin (TTR, formerly called prealbumin) was proposed as nutritional marker in The Lancet in 1972 [1]. This proposal was largely disregarded by the scientific community during the decade following its publication. Starting from the beginning of the eighties, and due to uninterrupted progress in fundamental and applied investigations, the TTR index turned progressively out to become an attractant for clinical nutritionists and for a growing number of scientists involved in basic research. TTR testing is now the most utilized nutritional marker worldwide, having received the strong support of the Prealbumin Consensus Group [2].

A minority of workers, however, remain doubtful [3] or even reluctant [4] to adopt TTR as nutritional index, stressing the point that its synthesis is also influenced by inflammatory conditions $[3,4]$ and by other extra-nutritional factors such as natural or synthetic corticosteroids [5] and androgens [6]. In addition, the information provided by TTR plasma concentrations may be overestimated in kidney failure [7]. These data are not disputable but they may also be extended to most other nutritional indices. Investigators who are standing on the foreground of such pitfalls, mainly in dialysis care units, number nevertheless among the most enthusiastic TTR users [8], showing that appropriate handling of the marker allows the recovery of its full scoring validity. Besides nephrologists, many pediatricians, gerontologists and oncologists also came to the same conclusion that TTR measurement fully meets its initial purpose [1], provided that the objective utilization of the parameter is associated with skillful clinical expertise.

*Address correspondence to this author at the Laboratory of Immunology, Centre Hospitalier LYON-SUD, 165, Chemin du Grand-Revoyet, 69495Pierre-Benite Cedex, France; Tel: + 334 78861256;

E-mail: Jacques.bienvenu@ @hu-lyon.fr
The aim of the present review paper is to clarify the complex relationships linking malnutrition and inflammation, throwing further insight into a nutrition domain of increasing public health importance and opening new avenues of research in elderly persons. Among all possible analytical methods, the measurement of TTR is best achieved using immunoprecipitation procedures which are characterized by least variation range and higher reproducibility [9].

\section{EVOLUTION, STRUCTURE AND FUNCTIONS}

TTR is a highly conserved protein in vertebrate species already secreted by the choroid plexus of reptiles 300 millions years ago and remaining confined within the cerebrospinal fluid (CSF) [10]. Synthesis and secretion of TTR by the liver evolved much later, about 100 millions years ago, in birds and eutherian mammals [11]. Production of TTR by the liver and by the choroid plexus is regulated separately [12], suggesting that the central nervous system (CNS) is somewhat protected against the metabolic and nutritional alterations affecting the rest of the body. The human TTR gene has been localized on the long arm of the chromosome 18q23 [13]. The nucleotide sequences of the entire TTR gene, including the 5' (transcription initiating site) and the 3' (untranslated site) flanking regions have been described $[14,15]$. The gene spans 6.9 kilobases $(\mathrm{kb})$ and consists of 4 exons and 3 introns $[14,15]$. The hepatic TTRmRNA measures $0.7 \mathrm{~kb}$ encoding a pro-TTR-monomer undergoing a cleaving process to release the native TTR monomer [16]. Four identical subunits comprising each 127 amino acids (AAs) coalesce noncovalently to generate the fully mature nonglycosylated molecule whose molecular mass (MM) reaches $55 \mathrm{kDa}$ [17]. Two binding sites for thyroid hormones are burried inside the central channel of the tetrameric TTR edifice [18]. The secondary, tertiary and quarternary conformation structures of the TTR protein have been reported using $1.8 \AA$ A Fourier analysis [18]. One TTR 
monomer is implicated in the carriage of a small companion protein $(21 \mathrm{kDa}$ as $\mathrm{MM})$ displaying a single binding site for all-trans-retinol, hence its RBP denomination [19]. X-ray crystallographic studies have shown that RBP possesses an eight-stranded $\beta$-barrel core that completely encapsulates the retinol molecule [20]. Under usual circumstances, RBP is almost entirely saturated with retinol, explaining that the 3 components of the retinol circulating complex (RCC) totalize $76 \mathrm{kDa}$ as $\mathrm{MM}$ and remain attached within close 1:1:1 stoichiometry [21]. Aggregation of TTR to holo-RBP occurs within the endoplasmic reticulum prior to extracellular RCC secretion [22].

The TTR protein was first discovered in human CSF in 1942 [23] and later in human serum where its capacity to transport thyroxine was rapidly recognized [24]. Its main physico-chemical characteristics were described by German workers who emphasize its unusual richness in tryptophan [25]. Human TTR transports about $20 \%$ of the intravascular pool of both thyroid hormones and at least $90-95 \%$ of the retinol circulating pool. The transthyretin appellation recommended by the International Nomenclature Committee [26] stresses the dual conveying role played by TTR in human beings. The biological half-life of TTR is approximately 2 days [27] whereas that of holo-RBP turns around half a day [28]. By contrast, apo-RBP devoid of its retinol ligand displays a significantly reduced half-life of $3.5 \mathrm{hr}$ [28] and undergoes rapid glomerular leakage with subsequent tubular disintegration and recycling of its AA residues. It is therefore assumed that TTR plays a less important role in the transport of thyroid hormones than for the safeguard of the retinol pool. TTR forms a small and stable intravascular pool poorly subjected to extravasation. Its main catabolic site is the liver, followed by muscle mass, skin and kidneys [29].

To our knowledge, no ethnic differences are reported up to now for the normal TTR molecule which may nevertheless display microheterogeneity [30] and tissue deposits throughout the normal ageing processes [31]. In contrast, TTR is characterized by a very large genetic polymorphism affecting about 100 different point mutations [32], leading to misfolded forms of the protein and occurrence of amyloid disorders in several organs. The first description of the clinical anomaly was reported by Andrade [33] whereas the causal link with a mutated form of TTR was established by Costa et al. [34]. Other potential physiological properties are assigned to the TTR molecule. The description of immune properties mimicking thymic hormonal activities have been attributed to the first ten AA residues of the TTR monomeric sequence [35]. The recent discovery that TTR may exert chymotrypsin-like proteolytic activity on apolipoprotein AI and possibly on other substrates confers to TTR potential roles in lipid metabolism [36]. The report of a TTR binding site for catecholaminergic compounds [37] identified as oxidation products of norepinephrine [38] suggests that TTR is involved in the control of behavioral attitudes [39]. The tetrameric TTR protein is recognized as a component of the normal pancreatic $\beta$-cell structure, preserving its integrity against the risk of apoptosis [40]. Finally, normal TTR production is required for the maturation of brain neural stem cells [41] and for the control of spatial reference memory performances [42] as shown by differentially affected biological patterns observed in knock-out mice lacking TTR synthesis.

\section{SIGNIFICANCE OF TTR THROUGHOUT THE HU- MAN LIFESPAN}

Plasma TTR belongs, together with serum-albumin (SA) and transferrin (TF) to the so-called family of liver-secreted visceral proteins currently proposed to assess protein nutritional status. Significant alterations in the levels of protein intakes by humans affect protein synthesis, turnover and breakdown and determine the outcome of total body $\mathrm{N}$ (TBN) regarded as the cornerstone of body building. Using a simple 2-compartmental model, the human body may schematically be divided into the fat mass (FM) and the fat-free mass (FFM), the latter aggregating most of TBN stores and almost all of the mineral constituents. TBN distributes within a metabolic pool (liver, intestine, thymoleucocytic tissue), a structural pool (muscle mass, skin, soluble collagen) both made up of exchangeable proteins with rapid and slow turnover rates, respectively, and a non-exchangeable pool (connective tissue, tendons, cytoskeleton) poorly responsive to metabolic and nutritional influences [43]. Anabolism occurs when the rate of AA incorporation into protein exceeds that of oxidative losses, yielding a positive NB. Catabolism is the result of protein breakdown prevailing over protein synthesis with NB turning negative [43]. The body of a healthy $70-\mathrm{kg}$ man of average height contains approximately $10.5 \mathrm{~kg}$ protein ( $15 \%$ by weight) or about $1.7 \mathrm{~kg} \mathrm{~N}$.

TTR is detected in the fetal blood as early as 8 weeks after conception [44]. Fetal TTR likely originates from dual sources. A minor part seems inherited passively from the pregnant mother through transplacental filtration [45]. The bulk of fetal TTR results from proper hepatic synthesis as indicated by presence of noticeable TTR-mRNA amounts in the early developmental stages of this organ [46]. This view is strengthened by the observation that maternal TTR blood levels are not correlated with those found in cord sera and do not appear to substantively influence infant values [47]. Increasing gestational age is accompanied by a slow and predictable rise in TTR values correlated with birth weight and proved useful in distinguishing between small, appropriate and large for gestational age infants $[47,48]$. The data are consistent with metabolic studies showing that the level of protein turnover in premature infants is inversely correlated with conceptual age, leading to relatively higher tissue $\mathrm{N}$ accretion rates than in term neonates [49]. Nutritional rehabilitation of very low birth weight infants indicates that the elevation of TTR plasma values is mainly determined by the amount of ingested protein and strongly correlated with $\mathrm{N}$ accretion rates [50-52], being even predictive of weight gain velocity [53].

Starting from birth until 100 years of age, our reference TTR values [54] are those collected in the monograph " $\mathrm{Se}$ rum Proteins in Clinical Medicine " edited by the Foundation for Blood Research. The plasma TTR concentrations in healthy neonates are approximately two thirds those measured in healthy mothers and thereafter increase slowly until the onset of puberty without displaying sexual differences. The rate of protein synthesis similarly increases linearly during the prepubertal period [55], consistent with superimposable $\mathrm{N}$ accretion rates [56]. It is of interest to note that TTR values distribute along Gaussian curves in healthy neonates [57] and in preadolescent children [58], forming therefore 
the substrate, all else equal, for epidemiological studies on protein nutritional status between population groups [59].

Human puberty is characterized by major hormonal and metabolic alterations leading to increased height velocity and weight gain [60]. The timely onset and effectual progress of puberty require close interrelationships between the effects triggered by growth hormone and its vassal network of insulin-like growth factors, by thyroid and steroid hormones, by insulin and sex hormones [60]. Androgen and estrogen activities converge in stimulating bone mineralization and growth but diverge on other effector tissues. Whereas androgens strongly promote the development of muscle mass in males while exerting lipolytic effects on visceral and subcutaneous adipocytes, estrogens entail minimal enlargement of the female musculature while stimulating the accrual of subcutaneous fat depots [60]. Body composition studies thus point to prepubertal redistribution of FM and FFM with a significantly higher S-shaped elevation of FFM in male adolescents compared with the blunted curve recorded in teenaged girls $[61,62]$. TTR values manifest closely paralleled sex- and age-peculiarities in process of time that are best explained by the deeper androgenic impregnation of male subjects $[6,43]$. The musculature is by weight the main component of FFM, representing $37 \%$ of body mass [61].

In healthy adults, the sex-related difference in plasma TTR-RBP concentrations is maintained in the form of plateau levels during full sexual maturity [54,63]. Normal TTR plasma values are stabilized around $290-320 \mathrm{mg} / \mathrm{L}$ in males and around $250-280 \mathrm{mg} / \mathrm{L}$ in females [54,63]. Starting from the sixties, TTR concentrations progressively decline over time, disclosing a steeper slope in elderly men that reflects a relatively more rapid deterioration of their muscle mass [43]. As a result, the earlier TTR sexual difference disappears by about the age of 70 years [43]. Again, this is in narrow correlation with the age-dependent curvilinear drop of TBN, characterized by an accelerated decrease after 65 years [64]. Taken together, the plasma TTR evolutionary patterns reveal in healthy individuals a striking parallelism with FFM, conferring to TTR the aptitude to serve as a reasonable indicator of muscle mass. The data show that age and gender are significant co-variates of TTR which require separate blood reference values [54]. In our hands, the TTR coefficient of variation for between-run precision in adult subjects is 3.8 $\%$.

\section{TTR AS INDEX OF PROTEIN DEPLETION / REPLE- TION STATES}

There exists a long-lasting debate aiming at identifying the most effective protein sources, level of energy-yielding substrates and the proportion among these for the support of protein metabolism. Under usual conditions, glucose functions as the major energy substrate for protein synthesis. If the carbohydrate energy is lacking, glucose must be synthesized by gluconeogenesis, mainly from the conversion of endogenous or dietary protein [65]. This increased AA oxidation corresponds to a form of nutritional wastage which augments the cost of protein synthesis, as documented by an increased urinary excretion of urea. The above metabolic pattern stands in broad conformity with the concept that " protein synthesis occurs in the flame of sugars " [66].
FAO / WHO / UNU recommends for healthy adults the safe level of $0.75 \mathrm{~g} \mathrm{k}^{-1} \mathrm{day}^{-1}$ protein intake [67]. Although this protein amount sustains normal growth and keeps unmodified the concentration of most biological parameters, such intake appears to be marginally inadequate to maintain the metabolic reserve capacities that are required to mount optimal responses to stress [68]. Recent turnover studies grounded on the recommended FAO/WHO/UNU protein intake consumed by healthy volunteers have disclosed that TTR plasma level and pool size remain unaltered just because its synthetic and catabolic rates are both downregulated concomitantly [69]. Changes occurring during prolonged starvation causes the $\mathrm{N}$ balance to turn negative despite efforts to minimize protein catabolism [70]. There is a direct correlation between the rate of liver protein synthesis and intrahepatic concentrations of individual free AAs [71]. It is likely that the dietary limitation of some AAs such as tryptophan [72] or leucine [73] could specifically exert inhibitory effects on the transcriptional [74] or translational [75] regulation of protein synthesis. Anyhow, protein depletion causes a decrease in TTR nuclear transcript that precedes the decrease in TTR mRNA [72,74,76]. Transcription of the TTR gene in the liver is directed by CCAAT/enhancer binding protein (C/EBP) bound to nuclear factor 1 (NF1) [74]. Multiple hepatocyte nuclear factors (HNFs) function in the regulation of TTR gene expression [77]. It has been recently shown that one of them $(\mathrm{HNF}-4 \alpha)$ plays prominent roles before and after injury [78]. The drop of liver TTRmRNA levels to about half as an effect of protein deprivation [74] is accompanied by a corresponding diminished secretion of mature TTR molecules in the bloodstream.

The rapidly turning over TTR protein is exquisitely sensitive to any change in protein and/or energy supply, being clearly situated on the cutting edge of the equipoise. This is documented in preterm infants in whom AA supply is responsible for maintaining normal protein synthesis which may be somewhat modulated by fluctuations in energy intake [79]. TTR is also useful to monitor the best $\mathrm{N}$ : energy balance of infants formulas [80] compared with breastfeeding [81] and to take appropriate dietetic guidelines in anorexia nervosa [82] or in weight-reducing programs [83]. Likewise, TTR is recommended for the nutritional follow-up of children suffering a variety of metabolic or genetic disorders such as uncontrolled diabetes [84], cystic fibrosis [85], sickle cell disease [86], Reye's syndrome [87], phenylketonuria [88] and defects of the urea cycle [89]. The drop of TTR reflects the inadequate provision of nutrient classes, setting in motion adaptive mechanisms which largely precede the development of clinical symptoms.

In the declared stage of protein malnutrition, the serial measurement of TTR may serve to grade the severity of the disease spectrum, from mild [90] to severe [1] forms. Both metabolic and structural $\mathrm{N}$ compartments undergo exhausting processes as documented by the fall of nitrogenous compounds in the urine of protein-depleted subjects [91]. The relative dominance of urea over ammonia catabolites [92] reflects the more intense turnover rate of tissues belonging to the readily mobilizable $\mathrm{N}$ pool. Decreased TTR plasma values are indeed correlated with the involution of the gut mucosa [93] and with the extent of liver dysfunction, more pronounced in the kwashiorkor disease with massive hepatic 
steatosis than in marasmus with limited fatty liver infiltration [1]. The structural $\mathrm{N}$ compartment nevertheless participates in the loss of body protein reserves, consistent with the reduced urinary output of creatinine [91], 3-methylhistidine [94] and soluble hydroxyproline [95]. The resulting sarcopenia $[96,97]$ and the concomitant depression of immune mechanisms $[98,99]$ render an account of the higher morbidity / mortality rates affecting TBN-depleted patients identified by the lowest TTR and RBP plasma concentrations [100]. The mortality risk of malnourished children in Central Africa becomes likely when SA and TTR reach the threshold of $16 \mathrm{~g} / \mathrm{L}$ and $65 \mathrm{mg} / \mathrm{L}$, respectively [101].

During nutritional rehabilitation from protein malnutrition, the restoration of visceral proteins occurs at different rates depending on the type of protein and the size of its plasma pool. TTR and RBP recovery appears as the main result of increased production rates by the liver [102]. This is at variance with the kinetic patterns observed for SA [103] and TF [104] whose plasma pool replenishment is achieved via changes in both synthetic and catabolic rates. The data stand in good agreement with multivariate analyses indicating that the outcome predictive ability of TTR is independent from that offered by SA and TF [100]. Most studies contend the view that the trajectory outlined for TTR correlates with the fluctuations of body $\mathrm{N}$ mass, especially during the anabolic phase of growth and clinical recovery from protein malnutrition. Using impedance parameters for assessing the $\mathrm{N}$ compartment still remaining in place in the stressed body of adults undergoing renal dialysis, nephrologists were able to demonstrate close relationships between TTR and phase angle, reactance and resistance values [105]. In elderly noninfected persons, FFM index measured by dual X-ray absorptiometry exhibits the highest correlation with TTR $(r=0.64)$ compared to RBP $(r=0.52)$ [106]

\section{TTR AS NITROGEN INDEX IN INFLAMMATORY DISORDERS}

Inflammatory disorders of any cause are initiated by activated leukocytes releasing a shower of cytokines working as autocrine, paracrine and endocrine molecules [107]. Cytokines regulate the overproduction of acute-phase proteins (APPs), notably that of CRP, $\alpha_{1}$-acid glycoprotein (AGP), fibrinogen, haptoglobin, $\alpha_{1}$-antitrypsin and antichymotrypsin [107]. APPs contribute in several ways to defense and repair mechanisms, being characterized by proper kinetic and functional properties [107]. Interleukin-6 (IL-6) is regarded as a key mediator governing both the acute and chronic inflammatory processes, as documented by data recorded on burn [108], sepsis [109] and AIDS [110] patients. IL-6-NF possesses a high degree of homology with $\mathrm{C} / \mathrm{EBP}-\mathrm{NF} 1$ and competes for the same DNA response element of the IL-6 gene [111]. IL-6-NF is not expressed under normal circumstances, explaining why APP concentrations are kept at baseline levels. In stressful conditions, IL-6-NF causes a dramatic surge in APP values [107,112] with a concomitant suppressed synthesis of TTR as demonstrated in animal [113] and clinical [114] experiments.

Under acute stressful conditions, protein turnover is strongly stimulated by augmented tissue breakdown (mainly in the muscle mass) and enhanced specific tissues synthesis (mainly in the liver and at the site of injury). Proteolysis re- leases AA residues which are preferentially incorporated into the hepatic precursor pool involved in the production of APPs $[115,116]$. The rate at which proteins are degraded generally exceeds the rate of AA mobilization for protein synthesis $[117,118]$ yielding a net negative NB associated with an increased urinary output of urea and ammonia [119]. Creatininuria and 3-methylhistidinuria are significantly elevated and remain highly correlated $(r=0.97)$ attesting to the substantial participation of the skeletal musculature to the stress responses [117]. The gap between degradative and synthetic processes widens in proportion to the severity of injury, resulting in correspondingly increased urinary $\mathrm{N}$ catabolites [43]. Serious injury affecting otherwise healthy adults may trigger urinary $\mathrm{N}$ losses reaching $40 \mathrm{~g} /$ day or 250 g/week, which corresponds to about $15 \%$ of TBN [43]. In long-lasting debilitating disorders, the persisting negative NB may deplete the baseline body cell mass by about $45 \%$, carrying ominous prognostic significance [120].

The peak of urinary $\mathrm{N}$ excretion culminates within 3 to 5 days after the onset of acute injury [121]. This coincides with the nadir recorded for the negative NB [122] and for TTR values [123]. When the stressful condition subsides, both NB and TTR levels improve and return to the physiological range within a couple of days provided that appropriate nutritional support is offered. In contrast, inadequate nutritional management [122], multiple injuries, occurrence of severe sepsis and metabolic complications result in persistent proteolysis [124] and subnormal TTR concentrations [66]. The evolutionary patterns of urinary $\mathrm{N}$ output and of TTR thus appear as mirror images of each other, which supports the view that TTR might well reflect the depletion of TBN in both acute and chronic disease processes. Even in the most complex stressful conditions, the synthesis of visceral proteins is submitted to opposing anabolic or catabolic influences yielding ultimately TTR as an end-product reflecting the prevailing tendency. Whatever the nutritional and/or inflammatory causal factors, the actual TTR plasma level and its course in process of time indicates the exhaustion or restoration of the body $\mathrm{N}$ resources, hence its likely (in)ability to assume defense and repair mechanisms. The serial measurement of TTR appears as a dynamic tool pointing to the direction and magnitude of NB, predicting therefore the disease outcome. Hundreds of studies are reporting the clinical usefulness of TTR measurement. We have hereunder pinpointed some among the most relevant investigations recommending TTR testing in routine clinical practice.

In pediatric settings, TTR is a marker of malnutrition both in septic and non-septic situations, revealing earlier sensitivity than common anthropometric approaches [49, 52, $53,125]$. The serial measurement of TTR is required to monitor the visceral protein response to nutritional supplementation in neonates recovering from major surgery [126]. In critically ill children parenterally refed, the mean protein intake was shown directly correlated with TTR and RBP plasma concentrations [127]. Low preoperative TTR values in infants undergoing cardiac surgery were predictive of more frequent postoperative complications [128]. TTR alerts the physician on the validity of his ongoing therapeutic strategy, helps to redress the balance of nutrient classes and foretells the outcome of severely ill children as survivors have higher initial TTR values than non-survivors [129]. 
TTR is also recommended for the assessment and nutritional follow-up of a large panel of hospitalized patients in internal medicine settings [130,131], in general surgery $[132,133]$ and intensive care units $[134,135]$. In particular, TTR is regarded as a useful tool for the therapeutic management of head injury [136], burn patients [137], for taking into charge respiratory failure [138], acute and chronic pancreatitis [139] and Crohn's disease [140]. Liver diseases are characterized by distinct TTR interpretation difficulties. The hepatic damages caused by biliary atresia [141], by viral or alcoholic cirrhosis [142], by acute [143] or chronic [144] hepatitis depress the production of TTR plasma concentrations that are usually correlated with impairment of liver function tests. Low TTR values thus appear to nonspecifically reflect the extent of liver damage rather than its etiology. Liver $\mathrm{N}$ tissue only represents by weight a minor proportion of TBN but its intense turnover rate (10 to 20 -fold more rapid than that of muscle tissue) [43] and its critical involvement in the orchestration of most major metabolic and immune pathways [145] explains why liver failure of any cause is usually associated with varying degrees of clinical malnutrition [142] mimicking the symptomatology of the above-described kwashiorkor / marasmus forms of protein depletion [1]. Patients undergoing liver transplantation suffer massive protein catabolism with a NB remaining negative many weeks postoperatively [146]. The data are in close relation with the postsurgical fall of TTR values during at least 3 weeks even in successful cases of graft livers [147], indicating that an extensive period of time is required before normalization of protein metabolism occurs. In a large cohort of 114 patients submitted to lung transplantation, a Cox proportional hazards model for overall survival has identified a pretransplant TTR threshold value $\leq 180 \mathrm{mg} / \mathrm{L}$ as a major mortality risk factor [148].

The nutritional management of kidney patients has met noticeable improvement along the past decades. Until the mid 1980s, and due to its catabolic dependence on renal function causing supranormal levels, TTR was regarded as unreliable and discarded, leaving the way for the general use of SA in kidney studies. The turning point came in 1987 when a careful statistical analysis stated that TTR was the most representative marker within a large battery of currently measured parameters [149]. This original investigation stating a TTR cut-off value of $300 \mathrm{mg} / \mathrm{L}$ below which kidney patients incur shortened survival rate has stimulated clinical approaches offering to TTR equal predictive opportunities to that of SA [150]. The most recent studies clearly incline towards the common use of TTR superseding that of SA [8, 151-155]. It has been confirmed, mainly in intensive care renal units, that the serial measurement of TTR works as a strong independent predictor of long-term survival, allowing to identify the patients in need of nutritional intervention $[151,155]$ or at risk of reduced life expectancy [154, 155]. Using proportional hazards regression models, the relative risk of death was inversely correlated to TTR concentrations in 8,157 hemodialyzed patients [155] who benefit from a $44 \%$ lower mortality risk in comparison with patients submitted to peritoneal dialysis [153]. TTR is currently measured as nutritional marker in tropical areas where bacterial, viral and parasitic diseases are still highly prevalent, usually in connection with defective immune and vitamin A status. It is the case for malaria in Thailand [156], for trypanosomiasis in Ivory Coast [157], schistosomiasis in Brazil [158], measles in Mali [159] and shigellosis in Bangladesh [160]. AIDS studies have shown that HIV-seropositive individuals reveal no significant difference from normal controls whereas declared AIDS patients exhibit declining TTR values as the morbid condition worsens [161].

In westernized societies, elderly persons constitute a growing population group. A substantial proportion of them may develop a syndrome of frailty characterized by weight loss, clumsy gait, impaired memory and sensorial aptitudes, poor physical, mental and social activities, depressive trends. Hallmarks of frailty combine progressive depletion of both structural and metabolic N compartments [162]. Sarcopenia and limitation of muscle strength are naturally involutive events of normal ageing which may nevertheless be accelerated by cytokine-induced underlying inflammatory disorders $[163,164]$. Depletion of visceral resources is substantiated by the shrinking of FFM and its partial replacement by FM, mainly in abdominal organs, and by the down-regulation of indices of growth and protein status [162]. Due to reduced tissue reserves and diminished efficiency of immune and repair mechanisms, any stressful condition affecting old age may trigger more severe clinical impact whereas healing processes require longer duration with erratical setbacks. As a result, protein malnutrition is a common finding in most elderly patients [165] with significantly increased morbidity and mortality rates [166,167]. Measurement of visceral protein status is proved useful throughout the entire ageing lifespan. Combining SA and TTR testing provides an accurate prediction in the prognosis of hospitalized geriatric patients already at the time of admission with additional suspicion of cancer status in the case of low values [168]. The follow-up of elderly patients submitted to surgical restoration of hip fracture reveals NB turning positive within 8-10 days in the absence of medical complications, consistent with the normalization of TTR values, whereas those afflicted by obstacle course are kept under negative NB with persisting subnormal TTR concentrations [169]. A wide range of co-morbidities associated with defective protein nutritional status is described in aging persons who become more prone to develop pressure sores [163], osteoporosis [170], oral candidiasis [171] and nuclear cataract [172].

The isolation and purification of rat TTR [173] has allowed to set up animal models. In normal rats, TTR manifests highly significant correlations with nutrient intakes and with visceral and carcass $\mathrm{N}$ stores [174]. In tumor-bearing rats, the progressive exhaustion of body protein mass towards cachexia states is correlated with declining TTR values [175]. TTR is currently utilized as indicator of protein nutritional status in cancer patients $[176,177]$. TTR is held as the most powerful test overall for evaluating visceral protein status of children with solid tumors [178] and leukemias [179] both at the time of diagnosis and throughout chemotherapy. In bone marrow transplantation for malignancies, TTR accurately reflects at any point changes in the patient's clinical status [180]. TTR has proved to be a useful marker of nutritional alterations with prognostic implications in large bowel cancer [181], bronchopulmonary carcinoid tumor [182], ovarian carcinoma [183] and bladder epithelioma [184]. Many oncologists have observed a rapid TTR fall 2 or 3 months prior to the patient's death [181]. In cancer patients submitted to surgical intervention, most postoperative com- 
plications occurred in subjects with preoperative TTR $\leq 180 \mathrm{mg} / \mathrm{L}$ [185]. Two independent studies came to the same conclusion that a TTR threshold of $100 \mathrm{mg} / \mathrm{L}$ is indicative of extremely weak survival likelihood and that these terminally ill patients better deserve palliative care rather than aggressive therapeutic strategies [185,186].

Most physicians interested in assessing nutritional status are currently using TTR as single protein index. New trends have occurred aiming at aggregating TTR with one or many reactants of the stressful response with a view to encompassing both nutritional and inflammatory facets of the disease spectrum. Under (sub)acute circumstances, the most frequently proposed association is by far the CRP/TTR ratio as documented in neonatal [187], adult [160] or postoperative infections [188], in myocardial infarction [189], renal insufficiency [190] or multiple organ failure [191]. The AGP/TTR couple is especially recommended in chronic inflammatory disorders, notably in several cancer types [192,193]. Working along the same lines is the prognostic inflammatory and nutritional index (PINI) [194] which is successfully applied on large cohorts of patients. TTR also participates in the development of screening formulas recently generated by innovative analytical tools such as surface-enhanced laser desorption/ionization (SELDI) or matrix-assisted laser desorption/ionization (MALDI) coupled with time of flightmass spectrometry (TOF-MS). The advent of these sophisticated and costly proteomic fingerprinting studies of serum or other biological fluids are nevertheless promising in that they tentatively strive to identify the early stages of several disease conditions such as hepatitis B [195], tuberculosis [196], Alzheimer's disease [197] or neoplastic disorders [198]. These proteomic detecting systems usually combine classical APP reactants with some minor biological compounds scarcely measured in routine laboratory practice such as cathepsin $\mathrm{D}$, hemopexin, neopterin or vitronectin. The fact that most, if not all, of these fingerprinting formulas embody TTR measurement indicates that there exists among workers a large consensus considering this carrier-protein as the most reliable indicator of protein depletion in morbid circumstances.

\section{PROGRESS IN TTR RESEARCH : THE BRAIN AGE- ING PROCESS}

Dementia, defined as significant memory impairment and loss of intellectual functions, is a common and devastating public health problem, affecting an estimated $2-4 \%$ individuals over the age of 65 years. Two distinct clinicopathological conditions are usually taken into consideration as causative factors: Alzheimer's disease (AD), a chronic and continuously progressing illness for which the only widely accepted risk conditions are age and family history of the disease; and cerebral infarction, a brain deteriorating process evolving along episodic and repetitive bouts so as to generate a syndrome of multi-infarct dementia (MID) [199]. The rates of both $\mathrm{AD}$ and MID increase dramatically with age, leading to coexisting pathologies with intermingled symptomatology [200]. In support to this mixed cases concept are the report of equally increased blood-brain barrier permeability in both AD and MID patients [201] and the accumulation of amyloid $\beta$-protein in the brain of MID subjects mimicking AD pathology [202]. There exists considerable overlap between $\mathrm{AD}$ and MID clinical symptoms, giving rise to a continuum of patients in whom pure AD and pure MID represent the two extreme poles [200].

Researchers involved in the pathogenesis of $\mathrm{AD}$ and MID are focusing their attention on two main targets, namely vasculature and brain tissue. Among the vascular risk factors and besides the already mentioned alterations of blood-brain barrier permeability [201], low-grade systemic inflammation as assessed by elevated IL-6 [203] and CRP [204] plasma values, could contribute to the activation of vascular endothelial cells. Rampant inflammation is associated with increased incidence of depression [205], of delirium [206] and reduced life expectancy [207]. In addition, the elevated homocysteine (Hcy) values found in AD patients [208,209] are reportedly associated with dementia [208,210]. Hyperhomocysteinemia is causally attributed to dietary deficiencies in water-soluble vitamins in the order of folates > cobalalamins $>$ pyridoxine $[211,212]$ although protein malnutrition is also incriminated as causative factor in a significant proportion of cases [213]. The resulting atherothrombogenesis is created by a variety of interwoven mechanisms, among which are Hcy-induced damage to the endothelial and vascular smoothmuscle cells, reduced synthesis and bioavailability of nitric oxide and overproduction of highly reactive oxidative byproducts [211,212].

The choroid plexus is the sole site of mammalian brain involved in TTR production [214]. Its synthesis rate by the choroid epithelium is estimated 25 to 100 times higher than that of the liver on a weight basis [215]. As a result, TTR is a major component of CSF, constituting 10 to $25 \%$ of total ventricular proteins [216] conveying up to $80 \%$ of intrathecal thyroxine [217]. TTR thus constitutes an hormonal carrierprotein fulfilling important ontogenic and functional properties in mammalian nervous structures, a concept further corroborated by the observation of its increased CSF concentration during the neonatal period [218]. The data imply that choroidal TTR facilitates the uptake of thyroxine from the bloodstream, governing its transport and delivery to brain tissues following a kinetic model developed by Australian workers [219]. In comparison, CSF contains 10 to 100 times lower RBP and retinol concentrations than plasma whilst retinyl esters from dietary origin are virtually absent [220]. Although it has been reported that minute amounts of RBP could be produced within the neuraxis [221], the sizeable proportion of retinol molecules required for brain maturation utilizes the RCC transport system to reach the choroid plexus. The RCC vehicle seems ideally suited to serve as a blood-brain conveying system as its size is close to that of SA (66 kDa as MM) known to undergo selective transmission [216]. The very high receptor binding affinity expressed by neural tissues for RBP molecules [222] is confined within the endothelial cells of the brain microvasculature and within the choroidal epithelial cells, the two primary sites of the mammalian blood-brain barrier [223]. The contrast between high RBP binding affinities and low intrathecal concentrations makes it likely that holo-RBP does not experience significant transchoroidal diffusion, strongly suggesting that its retinol ligand is released in free form and readily taken up by membrane or intracellular receptors of neural cells. The dual TTR production, plasma-derived and choroid-secreted, allows complementary stimulation of brain activities. Thyroid hormones and retinoids indeed function in concert through the mediation of common heterodimeric motifs bound to 
DNA response elements [224,225]. The data also imply that the provision of thyroid molecules within the CSF works as a relatively stable secretory process, poorly sensitive to extracerebral influences [12] as opposed to the delivery of retinoid molecules whose plasma concentrations are highly dependent on nutritional and / or inflammatory alterations [66]. This last statement is documented by mice experiments [226] and clinical investigations [227] showing that the level of TTR production by the liver operates as a limiting factor for retinol transport. Defective TTR synthesis determines the occurrence of secondary hyporetinolemia which nevertheless results from entirely different kinetic mechanisms in the two quoted studies $[226,227]$. In the TTR knock-out mice model, holoRBP molecules are normally synthetized and secreted by the liver but undergo rapid kidney leakage in the absence of stabilizing TTR molecules [228]. Despite very low levels of plasma retinol (about $5 \%$ of wild type), these targeted mutated animals remain healthy and fertile, implying that efficient compensatory mechanisms take place. No such increased urinary output of RBP molecules occurs in malnourished patients who develop in proportion to their declining protein status electroretinographic abnormalities and ocular lesions which are pathognomonic symptoms of vitamin Adeficiency [229]. During nutritional rehabilitation of malnourished subjects, the $3 \mathrm{RCC}$ components gradually return to normal ranges even without retinol or carotene supplementation, indicating that the retinyl esters normally sequestered in liver stellate cells mandatorily need diet-induced synthesis of new TTR molecules before undergoing retinol conversion and binding as holo-RBP ligand [227]. The prominent place occupied by TTR in defining distal retinoid bioavailability has been too long unrecognized despite the warning expressing that " overlooking the crucial role of TTR in vitamin A-metabolism results in unachieved or even misleading conclusions " [66].

Retinol is a precursor substrate that must undergo a twostep oxidation procedure to release firstly retinal and thereafter the two active all-trans- and 13-cis-retinoic acids (RAs) $[225,230]$. The latter converting steps are regulated by retinaldehyde dehydrogenase (RALDH) enzymes whose major sites of expression are the olfactory bulb, the striatum and the hippocampus [231,232]. The intracellular activities exerted by retinoid compounds are mediated by a large variety of specific receptors among which are cellular-RBP (CRBP), cellular-RA-BP (CRABP), RA-nuclear receptors (RARs) and retinoid $\mathrm{X}$ receptors (RXRs), each composed of 3 subtypes $\alpha, \beta, \gamma[225,232]$. Retinol is the rate-limiting determinant of the concentration of both RA derivatives [233], implying that any fluctuation in protein status might entail corresponding alterations in the cellular bioavailability of retinoid compounds, with all the more rapid effects as all-transRA has a short biological half-life of less than $1 \mathrm{hr}$ [234]. Because protein malnutrition is a common finding in as much as $50 \%$ of elderly AD and MID patients [235], many of them could well suffer permanent hyporetinolemia still accelerating the declining concentration of retinoid molecules observed over the course of normal ageing [231].

Dietary vitamin A is required to modulate early development of brain structure and differentiation [236] together with neuronal plasticity, memory functioning and neurotransmitter signaling during adulthood [237]. The normal decrease of brain retinoid molecules throughout the ageing process principally affects the above-described major sites of RA synthesis [238], a regressive alteration even more pronounced in AD patients [231]. In murine models, early depletion of retinoids causes deposition of amyloid $\beta$-peptides [239], initiating the formation of Alzheimer plaques. In aged animals, cognitive and memory deficits are associated with down-regulation of the expression of retinoid receptors which may recover their full activities under RA supplementation [240]. Administration of RA similarly restores expression of proteins involved in the control of amyloidogenic pathways [241]. Along the same preventive line is the demonstration that retinol disaggregates preformed amyloid $\beta$ fibrils, more effectively than does RA [242].

Alternatively, TTR participates in the maintenance of memory and normal cognitive processes during ageing by acting on the retinoid signalling pathway as recently reported on TTR-null knock-out mice model [42,243]. Moreover, TTR may bind amyloid $\beta$-peptide in vitro, preventing its transformation into amyloid neurofibrils [244]. Finally, marginal protein malnutrition, as assessed by diminished TTR plasma values, causes the elevation of Hcy concentrations [245]. There exists indeed an inverse correlation between both TTR and Hcy parameters, explaining why malnourished elderly persons incur increasing risk of Hcy-depended thrombovascular complications [213]. The defective mechanism is situated at the level of cystathionine- $\beta$-synthase $(\mathrm{C} \beta S)$, an enzyme governing the crossroad of remethylation and transsulfuration pathways [246]. Japanese workers have recently provided experimental validation of the metabolic anomaly, showing that rats given methionine (Met)-deprived nutriture manifest depressed C $\beta S$ activity with subsequent elevation of Hcy plasma levels [247]. Among all essential AAs consumed in human nutrition, Met is regarded as the most critically available because its withdrawal from the customary diet causes the deepest negative NB, being almost as great as when a protein-free regimen is ingested [248]. Met is implicated in a large spectrum of metabolic and enzymic activities and participates in the conformation of a large number of molecules of survival importance [213]. Due to the fact that plant products are relatively Met-deficient, vegan subjects are more exposed than omnivorous to develop hyperhomocysteinemia - related disorders [249]. In addition to water-soluble vitamin deficiencies, dietary protein restriction may promote supranormal Hcy concentrations which appear as the dark side of adaptive attempts developed by the malnourished and/or stressed body to preserve Met homeostasis.

Summing up, we assume that the low TTR concentrations reported in the blood [235] and CSF [250] of AD or MID patients result in impairment of their normal scavenging capacity [244] and in the excessive accumulation of Hcy in body fluids [245], hence causing direct harmful damage to the brain vasculature. In addition, depressed TTR concentrations indirectly inhibit the multitude of retinoid-dependent cerebral functioning pathways $[231,243]$ allowing the development of amyloidogenic processes [239]. The practical consequences of these findings imply that the correct assessment of nutritional status is recommended in all elderly patients. The mental and cognitive dysfunctions of old age that are not genetically programmed but result from varying energy, pro- 
tein and vitamin-deficiencies may be substantially prevented and sometimes improved provided that appropriate nutritional measures are undertaken.

\section{CONCLUDING REMARKS}

In spite of classical criticisms [3,4], TTR is regarded as a robust and reliable indicator of protein nutritional status by clinicians belonging to most medical disciplines. Measurement of TTR is a simple, rapid, inexpensive and accurate micromethod [251]. TTR exhibits rising and superimposable values in prepubertal children, displays sexual difference at the onset of adolescence and during adulthood, thereafter decreasing in elderly subjects. Taking into account these gender- and age-specificities, TTR appears as the sole plasma protein reflecting the fluctuations of TBN pools. The relationship linking alterations of TTR plasma levels with body $\mathrm{N}$ reserves are documented both in animal models [175] and in human subjects [105,106].

Uncomplicated malnutrition primarily affects the metabolic $\mathrm{N}$ pool, reducing protein syntheses and NB to levels compatible with survival, an adaptive response well identified by declining TTR values. In inflammatory disorders, both metabolic and structural $\mathrm{N}$ pools participate in varying proportions in the cytokine-induced responses of the stressed body, resulting in TBN shrinking and concomitant depression of TTR concentrations. Abatement of the stressful condition and / or efficient nutritional rehabilitation allows restoration to normal levels of both TBN pools and TTR values following parallel slopes. TTR thus appears as a dynamic index predicting the outcome of the disease. We attached more importance to the trend outlined by its serial appraisal than to any single measurement. The interval of time between 2 consecutive samplings should depend on the severity and evolution of the morbid condition. We recommend daily periodicity in distressed neonates, intensive care and transplantation patients, bi-weekly frequency in medical or surgical conditions of medium severity and monthly sequence in chronically evolving disorders.

Whatever the causal factor, depletion of TBN reserves attenuates the body's capacity to mount appropriate immune and repair mechanisms. A number of clinical investigations have advocated the level of plasma TTR as predictor of the length of hospital stay (LOS) and of mortality rate [252255]. TTR values situated under $180 \mathrm{mg} / \mathrm{L}$ constitute a boundary below which serious complications are to be expected [148,185]. In cancer patients, the threshold of $100 \mathrm{mg}$ TTR / L is regarded as harbinger of death $[185,186]$ which may be anticipated 2 or 3 months before the lethal outcome [181]. The same TTR predictive capacity has been reported in kidney patients whose relative risk of death is found inversely correlated with TTR plasma values $[154,155,190]$. Not surprisingly, unrecognized malnutrition entails longer LOS, increased number of complications and higher care costs whereas early detection and treatment of high risk patients significantly alleviate the financial burden of hospitalization while improving the prognostic outcome of the patients [252-256]. The last statement is documented by the first prospective and randomized survey showing that reduced morbidity and mortality rates are depending on protein $\mathrm{N}$ intake and correlated with rising TTR concentrations
[257]. We recommend that the measurement of TTR be universally applied as an integral part of any curative process.

The last section devoted to brain maturation and functioning in elderly persons paves the way for new diagnostic and therapeutic approaches. The revival of older RCC studies [227] allows to throw deeper insight into more recent findings [236-244] and to enlarge the scope of current research. Our data support the view that AD should no longer be considered as a distinct nosological entity but rather as forming a continuum with MID disorders, consistent with previous anatomoclinical features [200]. If that hypothesis holds true would mean that the varying clinical symptoms of both diseases spectrum would result from intricated factors among which gender, age, individual vulnerability and relative impact of protein-, retinoid- and vitamin-deficiencies take part, ultimately harming cerebral structures. TTR plays a pivotal role in that scenario : subnormal TTR plasma values commonly found in AD and MID patients [235] should inform the clinician that, besides overall TBN depletion, something goes wrong in protein metabolism, in TTR behavior or transport capacity. It could be disruption of Met homeostasis [213], inability to exert cleansing [239,244] or disintegrating [242] properties on amyloid $\beta$-fibril deposits, or a combination of these. Providing elderly persons with optimal protein nutritional status in order to insure their protection against the risk of neurodeterioration is the last message released by the fascinating TTR plasma protein.

\section{CONFLICT OF INTEREST STATEMENT}

The authors of the present review article have no financial, scientific or personal conflict of interest with other people, companies or organizations.

\section{ACKNOWLEDGMENTS}

The authors acknowledge the analytical information and kind assistance provided by scientists belonging to the Foundation for Blood Research, Scarborough, Maine, USA during the preparation of the manuscript.

\section{REFERENCES}

[1] Ingenbleek, Y.; De Visscher, M.; De Nayer, P. Lancet, 1972, 2, 106.

[2] Bernstein, L.H.; Bachman, T.E.; Meguid, M.; Ament, M.; Baumgartner, T.; Kinosian, B.; Martindale, R.; Spiekerman, M. Nutrition, 1995, 11, 169.

[3] Shenkin, A. Clin. Chem., 2006, 52, 2177.

[4] Johnson, A.M.; Merlini, G.; Sheldon, J.; Ichihara, K. Clin. Chem. Lab. Med., 2007, 45, 419.

[5] Georgieff, M.K.; Sasanow, S.R.; Mammel, M.C.; Ophoven, J.; Pereira, G.R. J. Pediatr., 1986, 108, 972.

[6] Braverman, L.E.; Ingbar, S.H. J. Clin. Endocrinol. Metab., 1967, $27,389$.

[7] Smith, F.R.; Goodman, D.S. J. Clin. Invest., 1971, 50, 2426.

[8] Sreedhara, R.; Avram, M.M.; Blanco, M.; Ratish, R.; Avram, M.M.; Mittman, N. Am. J. Kidney Dis., 1996, 28, 937.

[9] Cardenas, D.; Blonde-Cynober, F.; Ziegler, F.; Cano, N.; Cynober, L. Clin. Nutr. 2001, 20, 276.

[10] Schreiber, G. Clin. Chem. Lab. Med., 2002, 40, 1200.

[11] Power, D.M.; Elias, N.P.; Richardson, S.J.; Mendes, J.; Soares, C.M.; Santos, C.R.A. Gen. Comp. Endocrinol., 2000, 119, 241.

[12] Dickson, P.W.; Aldred, A.R.; Bannister, D.; Schreiber, G. J. Biol. Chem., 1986, 261, 3475.

[13] Wallace, M.R.; Naylor, S.; Kluve-Beckerman, B.; Long, G.L.; McDonald, L.; Shows, T.B.; Benson, M.D. Biochem. Biophys. Res. Commun., 1985, 129, 753. 
[14] Tsuzuki, T.; Mita, S.; Maeda, S.; Araki, S.; Shimada, K. J. Biol. Chem., 1985, 260, 12224.

[15] Sasaki, H.,; Yoshioka, M.; Tagaki, Y.; Sakaki, Y. Gene, 1985, 37, 191.

[16] Soprano, D.R.; Herbert, J.; Soprano, K.; Schon, E.A.; Goodman, D.S. J. Biol. Chem., 1985, 260, 11793.

[17] Kanda, Y.; Goodman, D.S.; Canfield, R.; Morgan, F. J. Biol. Chem., 1974, 249, 6796.

[18] Blake, C.C.F.; Geisow, M.J.; Oatley, S.J.; Rérat, B.; Rérat, C. J. Mol. Biol., 1978, 121, 339.

[19] Kanai, M.; Raz, A.; Goodman, D.S. J. Clin. Invest., 1968, 47, 2025.

[20] Newcomer, M.E.; Jones, T.A.; Åqvist, J.; Sundelin, J.; Eriksson, U.; Rask, L.; Peterson, P.A. EMBO J., 1984, 3, 1451.

[21] Monaco, H.L. Clin. Chem. Lab. Med., 2002, 40, 1229.

[22] Melhus, H.; Nilsson, T.; Peterson, P.A.; Rask, L. Exp. Cell Res., 1991, 197, 119.

[23] Kabat, E.A.; Moore, D.; Landow, H. J. Clin. Invest., 1942, 21, 571.

[24] Ingbar, S.H. Endocrinology, 1958, 63, 256.

[25] Schultze, H.E.; Schönenberger, M.; Schwick, G. Biochem. Z., 1956, 328, 267.

[26] Goodman, D.S.; Peters, T.; Robbins, J.; Schwick, G. J. Biol. Chem., 1981, 256, 12.

[27] Socolow, E.L.; Woeber, K.A.; Purdy, R.H.; Holloway, M.T.; Ingbar, S.H. J. Clin. Invest., 1965, 44, 1600.

[28] Peterson, P.A.; Nilsson, S.; Ostberg, L.; Rask, L.; Vahlquist, A. Vitam. Horm., 1974, 32, 181.

[29] Makover, A.; Moriwaki, H.; Ramakrishnan, R.; Saraiva, M.J.M.; Blaner, W.S.; Goodman, D.S. J. Biol. Chem., 1988, 263, 8598

[30] Pettersson, T.; Carlström, A.; Jörnvall, H. Biochemistry, 1987, 26, 4572.

[31] Westermark, P.; Sletten, K.; Johansson, B.; Cornwell, G.G. III. Proc. Natl. Acad. Sci. USA., 1990, 87, 2843.

[32] Ando, Y.; Nakamura, M.; Araki, S. Arch. Neurol., 2005, 62, 1057.

[33] Andrade, C. A. Brain, 1952, 75, 408.

[34] Costa, P.P.; Figueira, A.; Bravo, F. Proc. Natl. Acad. Sci. USA., 1978, 75, 4449 .

[35] Burton P.M.; Horner, B.L.; Jones, G.; Lin, T.; Nestor, J.J. Jr.; Newman, S.R.; Parks, T.L.; Smith, A.J.; White, A. Int. J. Immunopharmacol., 1987, 9, 297.

[36] Liz, M.A.; Faro, C.J.; Saraiva, M.J.; Sousa, M.M. J. Biol. Chem., 2004, 279, 21431.

[37] de Vera, N.; Cristófol, R.; Rodrígues Farré, E. Life Sci., 1988, 43, 1277.

[38] Boomsma, F.; Man In 't Veld, A.J.; Schalekamp, M.A.D.H. J. Pharmacol. Exp. Ther., 1991, 259, 551.

[39] Sousa, J.C.; Grandela, C.; Fernandez-Ruiz, J.; de Miguel R.; de Sousa, L.; Magalhaes, A.I.; Saraiva, M.J.; Sousa, N.; Palha, J.A. J. Neurochem., 2004, 88, 1052.

[40] Refai, E.; Dekki, N.; Yang, S.N.; Imreh, G.; Cabrera, O.; Yu, L.; Yang, G.; Norgren, S.; Rössner, S.M.; Inverardi, L.; Ricordi, C.; Olivecrona, G.; Andersson, M.; Jörnvall, H.; Berggren, P.O.; Juntti-Berggren, L. Proc. Natl. Acad. Sci. USA., 2005, 102, 17020.

[41] Richardson, S.J.; Lemkine, G.F.; Alfama, G.; Hassani, Z.; Demeneix, B.A. Neurosci. Lett., 2007, 421, 234.

[42] Sousa, J.C.; Marques, F.; Dias-Ferreira, E.; Cerqueira, J.J.; Sousa, N.; Palha, J.A. Neurobiol. Aging, 2007, 28, 713.

[43] Ingenbleek, Y.; Young, V.R. Clin. Chem. Lab. Med., 2002, 40, 1281.

[44] Andreoli, M.; Robbins, J. J. Clin. Invest., 1962, 41, 1070

[45] Gitlin, D.; Kumate, J.; Urrusti, J.; Morales, C. J. Clin. Invest., 1964, 43, 1938.

[46] Makover, A.; Soprano, D.R.; Wyatt, M.L.; Goodman, D.S. Differentiation, 1989, 40, 17.

[47] Sasanow, S.R.; Spitzer, A.R.; Pereira, G.R.; Heaf, L.; Watkins, J.B. J. Pediat. Gastroenterol. Nutr., 1986, 5, 111.

[48] Vahlquist, A.; Rask, L.; Peterson, P.A.; Berg, T. Scand. J. Clin. Lab. Invest., 1975, 35, 569 .

[49] Nissim, I.; Yudkoff, M.; Pereira, G.; Segal, S. J. Pediatr. Gastroenterol. Nutr., 1983, 2, 507.

[50] Thomas, M.R.; Massoudi, M.; Byrne, J.; Mitchell, M.A.; Eggert, L.D.; Chan, G.M. J. Parenter. Enter. Nutr., 1988, 12, 162.

[51] Polberger, S.K.; Fex, G.; Raiha, N.C. Acta Paediatr. Scand., 1990, 79, 729 .

[52] Kashyap, S.; Schulze, K.F.; Forsyth, M.; Dell, R.B.; Ramakrishnan, R.; Heird, W.C. Am. J. Clin. Nutr., 1990, 52, 254.
[53] Georgieff, M.K.; Sasanow, S.R.; Pereira, G.R. J. Pediatr. Gastroenterol. Nutr., 1987, 6, 775.

[54] Bienvenu, J.; Jeppson, J.0.; Ingenbleek, Y. In Serum Proteins in Clinical Medicine; Ritchie RF, Navolostkaia 0, Eds.; Foundation for Blood Research: Scarborough, 1996; Vol. 1, pp. 9.011-18.

[55] Young, V.R.; Steffe, W.P.; Pencharz, P.B.; Winterer, J.B.; Scrimshaw, N.S. Nature, 1975, 253, 192.

[56] Fomon, S.J.; Haschke, F.; Ziegler, E.E.; Nelson, S.E. Am. J. Clin. Nutr., 1982, 35, 1169.

[57] Warner, A.; Jang, R. Ann. Clin. Lab. Sci., 1999, 20, 398.

[58] Ingenbleek, Y. Ph. D. Thesis, University of Louvain, 1977.

[59] Reifen, R.; Haftel, L.; Manor, G.; Sklan, D.; Edris, M.; Khoshoo, V; Ghebremeskel, K. Nutrition, 2003, 19, 427.

[60] Veldhuis, J.D.; Roemmich, J.N.; Richmond, E.J.; Rogol, A.D.; Lovejoy, J.C.; Sheffield-Moore, M.; Mauras, N.; Bowers, C.Y. Endocr. Rev., 2005, 26, 114.

[61] Lohman, T.G. Advances in Body Composition Assessment. Monograph 3. Human Kinetic Publisher: Champaign, 1992

[62] Forbes, G.B. Human Body Composition. Growth, Aging, Nutrition and Activity, Springer-Verlag, Berlin, 1987.

[63] Ingenbleek, Y.; De Visscher, M. Metabolism, 1979, 28, 9.

[64] Hansen, R.D.; Raja, C.; Allen, B.J. In In Vivo Body Composition Studies; Yasamura S, Wang J, Pierson RN Jr, Eds.; New York Academy of Sciences: New York, 2000; pp. 345-52.

[65] Young, V.R.; Yu, Y.M.; Fugakawa, N.K. In Energy, Metabolism, Tissue Determinants and Cellular Corollaries; Kinney JM, Tucker HN, Eds; Raven Press: New York, 1992; pp. 439-66.

[66] Ingenbleek, Y.; Young, V.R. Annu. Rev. Nutr., 1994, 14, 495.

[67] FAO/WHO/United Nations University. Energy and Protein Requirements. Report of a Joint FAO/WHO/UNU Expert Group. Technical Report $\mathrm{N}^{\circ}$ 724. WHO: Geneva, 1985.

[68] Young, V.R.; Marchini, J.S. Am. J. Clin. Nutr., 1990, 51, 270

[69] Afolabi, P.R.; Jahoor, F.; Gibson, N.R.; Jackson, A.A. Am. J. Physiol. Endocrinol. Metab., 2004, 287, E327.

[70] Cahill, G.F. Jr. Clin. Endocrinol. Metab., 1976, 5, 397.

[71] Wannemacher, R.W. Jr.; Wannemacher, C.F.; Gyatrin, M.B. Biochem. J., 1971, 124, 385.

[72] Marten, N.W.; Burke, E.J.; Hayden, J.M.; Straus, D.S. FASEB J., 1994, 8,538 .

[73] Fafournoux, P.; Bruhet, A.; Jousse, C. Biochem. J., 2000, 351, 1.

[74] de Jong, F.A.; Schreiber, G. J. Nutr., 1987, 117, 1795.

[75] Kimball, S.R. J. Nutr., 2002, 132, 883.

[76] Straus, D.S.; Marten, N.W.; Hayden, J.M.; Burke, E.J. J. Nutr., 1994, 124,1041

[77] Costa, R.H.; Grayson, D.R.; Darnell, J.E. Jr. Mol. Cell. Biol., 1989, 9, 1415.

[78] Wang, Z.; Burke, P.A. J. Mol. Biol., 2007, 371, 323.

[79] Moscowitz, S.R.; Pereira, G.; Spitzer, A.; Heaf, L.; Amsel, J.; Watkins, J.B. J. Pediatr., 1983, 102, 744.

[80] Kashyap, S.; Forsyth, M.; Zucker, C.; Ramakrishnan, R.; Dell, R.B.; Heird, W.C. J. Pediatr., 1986, 108, 955.

[81] Kurugol, Z.; Coker, M.; Coker, C.; Egemen, A.; Ersoz, B. Turk. J. Pediatr., 1997, 39, 195.

[82] Symreng, T.; Cederblad, G.; Croner, S.; Larsson, J.; Schildt, B. Clin. Nutr., 1985, $4,81$.

[83] Gofferje, H.; Kozlik, V. Infusionsther. Klin. Ernähr., 1977, 4, 320.

[84] Kobbah, A. M.; Hellsing, K.; Tuvemo, T. Acta Paediatr. Scand. 1988, 77,734 .

[85] Adde, F.V.; Dolce, P.; Tanikawa, C.E.; Uehara, D.Y.; Cardoso, A.L.; Rozov, T. J. Pediatr. (Rio), 1997, 73, 317.

[86] Jain, S.K.; Ross, J.D.; Duett, J.; Herbst, J.J. Am. J. Med. Sci., 1990, 299, 13.

[87] Bosin, E.; Glasgow, A.M.; Monji, N. Clin. Biochem., 1986, 19, 189.

[88] Arnold, G.L.; Vladutiu, C.J.; Kirby, R.S.; Blakely, E.M.; De Luca, J.M. J. Pediatr., 2002, 141, 243.

[89] Acosta, P.B.; Yannicelli, S.; Ryan, A.S.; Arnold, G.; Marriage, B.J.; Plewinska, M.; Bernstein L.; Fox, J.; Lewis, V.; Miller, M.; Velazquez, A. Mol. Genet. Metab., 2005, 86, 448.

[90] Ogunshina, S.O.; Hussain, M.A. Am. J. Clin. Nutr., 1980, 33, 794.

[91] Schendel, H.E.; Hansen, J.D. Am. J. Clin. Nutr., 1965, 17, 36.

[92] Soares, M.J.; Piero, L.S.; Shetty, P.S.; Jackson, A.A.; Waterlow, J.C. Clin. Sci., 1994, 86, 441.

[93] McMillan, S.A.; Dickey, W.; Douglas, J.P.; Hughes, D.F. J. Clin. Pathol., 2001, 54, 783 . 
[94] Nagabhushan, V.S.; Narasinga Rao, B.S. Am. J. Clin. Nutr., 1978, 31, 1322.

[95] Picou, D.; Alleyne, G.A.O.; Seakins, A. Clin. Sci., 1965, 29, 517.

[96] Heymsfield, S.B.; McManus, C.; Stevens, V.; Smith, J. Am. J. Clin. Nutr., 1982, 35, 1192

[97] Briend, A.; Garenne, M.; Maire, B.; Fontaine, O.; Dieng, F. Eur. J. Clin. Nutr., 1989, 43, 715.

[98] Smythe, P.M.; Brereton-Stiles, G.G.; Grace, H.J.; Mafoyane, A.; Schonland, M.; Coovadia, H.M.; Loening, W.E.; Parent, M.A.; Vos, G.H. Lancet, 1971, 2, 939.

[99] Moulias, R.; Deville-Chabrolle, A.; Congy, F.; Wang, A.; Marescot, M.R.; Lesourd, B. In Nutrition, Immunity and Illness in the Elderly; Chandra, R.K., Ed.; Pergamon Press: New York, 1986; pp. 165-72.

[100] Brasseur, D.; Hennart, P.; Dramaix, M.; Bahwere, P.; Donnen, P.; Tonglet, R.; Devreker, T.; Duchateau, J. J. Pediatr. Gastroenterol. Nutr., 1994, 18, 220

[101] Dramaix, M.; Brasseur, D.; Donnen, P.; Bawhere, P.; Porignon, D.; Tonglet, R.; Hennart, P. Am. J. Epidemiol., 1996, 143, 1235.

[102] Morlese, J.F.; Forrester, T.; Del Rosario, M.; Frazer, M.; Jahoor, F. J. Nutr., 1998, 128, 214

[103] Morlese, J.F.; Forrester, T.; Badaloo, A.; Del Rosario, M.; Frazer, M.; Jahoor, F. Am. J. Clin. Nutr., 1996, 64, 952.

[104] Morlese, J.F.; Forrester, T.; Del Rosario, M.; Frazer, M.; Jahoor, F. J. Nutr., 1997, 127, 1469 .

[105] Mushnick, R.; Fein, P.A.; Mittman, N.; Goel, N.; Chattopadhyay, J.; Avram, M.M. Kidney Int. Suppl., 2003, 87, 553.

[106] Sergi, G.; Coin, A.; Enzi, G.; Volpato, S.; Inelmen, E.M.; Buttarello, M.; Peloso, M.; Mulone, S.; Marin, S.; Bonometto, M. Eur. J. Clin. Nutr., 2006, 60, 203.

[107] Bienvenu, J.; Monneret, G.; Fabien N.; Revillard. J.P. Clin. Chem. Lab. Med., 2000, 38, 267.

[108] de Bandt, J.P.; Chollet-Martin, S.; Hernvann, A.; Lioret, N.; du Roure L.D.; Lim, S.K.; Vaubourdolle, M.; Guechot, J.; Saizy, R.; Giboudeau, J. J. Trauma, 1994, 36, 624

[109] Hack, C.E.; De Groot, E.R.; Felt-Bersma, R.J.; Nuijens, J.H.; Strack Van Schijndel, R.J.; Eerenberg-Belmer, A.J.; Thijs, L.G.; Aarden, L.A. Blood, 1989, 74, 1704.

[110] Birx, D.L.; Redfield, R.R.; Tencer, K.; Fowler, A.; Burke, D.S.; Tosato, G. Blood, 1990, 76, 2303.

[111] Isshiki, H.; Akira, S.; Sugita, T.; Nishio, Y.; Hashimoto, S.; Pawlowski, T.; Suematsu, S.; Kishimoto, T. New Biol., 1991, 3, 63.

[112] Heinrich, P.C.; Castell, J.V.; Andus, T. Biochem. J., 1990, 265, 621.

[113] Murakami, T.; Ohnishi, S.; Nishiguchi, S.; Maeda, S.; Araki, S.; Shimada, K. Biochem. Biophys. Res. Commun., 1988, 155, 554.

[114] Banks, R.E.; Forbes, M.A.; Storr, M.; Higginson, J.; Thompson, D.; Raynes, J.; Illingworth, J.M.; Perren, T.J.; Selby, P.J.; Whicher, J.T. Clin. Exp. Immunol., 1995, 102, 217.

[115] Long, C.L.; Jeevanandam, M.; Kim, B.M,; Kinney, J.M. Am. J. Clin. Nutr., 1977, 30, 1340.

[116] Hasselgren, P.O.; Pedersen, P.; Sax, H.C.; Warner, B.W.; Fisher, J.E. Arch. Surg., 1988, 123, 992.

[117] Tomkins, A.M.; Garlick, P.J.; Schofield, W.N.; Waterlow, J.C. Clin. Sci., 1983, 65, 313

[118] Arnold, J.; Campbell, I.T.; Samuels, T.A.; Devlin, J.C.; Green, C.J.; Hipkin, L.J.; MacDonald, I.A.; Scrimgeour, C.M.; Smith, K.; Rennie, M.J. Clin. Sci., 1993, 84, 655

[119] Burge, J.C.; Choban, P.; McKnight, T.; Kyler, M.K.; Flancbaum, L. J. Parenter. Enter. Nutr., 1993, 17, 529.

[120] Kotler, D.P.; Tierney, A.R.; Wang, J.; Pierson, R.N. Jr. Am. J. Clin. Nutr., 1989, 50, 444

[121] Cuthbertson, D.P. Lancet, 1942, $i, 433$.

[122] Hoover, H.C. Jr.; Ryan. J.A.; Anderson, E.J.; Fisher, J.E. Am. J. Surg., 1980, 139, 153

[123] Kasper, H.; Brodersen, M.; Schedel, R. Acta HepatoGastroenterol., 1975, 22, 403.

[124] Finn, P.J.; Planck, L.D.; Clark, M.A.; Connolly, A.B.; Hill, G.L. Lancet, 1996, 347, 654.

[125] Malave, I.; Vethencourt, M.A.; Pirela, M.; Cordero, R.; Baute, L.; Acuna, M.; Sousa, P. Arch. Latinoam. Nutr., 1996, 46, 203.

[126] Chwals, W.J.; Fernandez, M.E.; Charles, B.J.; Schroeder, L.A.; Turner, C.S. J. Pediatr. Surg., 1992, 27, 317.

[127] Helms, R.A.; Dickerson, R.N.; Ebbert, M.L.; Christensen, M.L.; Herrod, H.G. J. Pediatr. Gastroenterol. Nutr., 1986, 5, 586
[128] Leite, H.P.; Fisberg, M.; Novo, N.F.; Nogueira, E.B.; Ueda, I.K. J. Saõ Paulo Med., 1995, 113, 706 .

[129] Briassoulis, G.; Zavras, N.; Hatzis, T. Nutrition, 2001, 17, 548

[130] Tuten, M.B.; Wogt, S.; Dasse, F.; Leider, Z. J. Parenter. Enter. Nutr., 1985, 9, 709.

[131] Devoto, G.; Gallo, F.; Marchello, C.; Racchi, O.; Garbarini, R.; Bonassi. S.; Albalustri, G.; Haupt, E. Clin. Chem., 2006, 52, 2281.

[132] Young, G.A.; Chem, C.; Hill, G.L. Am. J. Clin. Nutr., 1978, 31, 429.

[133] Ihara, H.; Matsumoto, T.; Shino, Y.; Hashizume, N; Takase, M.; Nagao, J.; Sumiyama, Y. J. Clin. Lab. Anal., 2003, 17, 1.

[134] Montecalvo, M.A.; Steger, K.A.; Farber, H.W.; Smith, B.F.; Dennis, R.C.; Fitzpatrick, G.F.; Pollack, S.D.; Korsberg, T.Z. Birkett, D.H.; Hirsch, E.F. Crit. Care Med., 1992, 20, 1377.

[135] Raguso, C.A.; Dupertuis, Y.M.; Pichard, C. Curr. Opin. Clin. Nutr. Metab. Care, 2003, 6, 211

[136] Nataloni, S.; Gentili, P.; Marini, B.; Guidi, A.; Marconi, P.; Busco, F.; Pelaia, P. Clin. Nutr., 1999, 18, 247.

[137] Cynober, L.; Prugnaud, O.; Lioret, N.; Duchemin, C.; Saizy, R.; Giboudeau, J. Surgery, 1991, 109, 640.

[138] Schlossmacher, P.; Hasselmann, M.; Meyer, N.; Kara, F.; Delabranche, X.; Kummerlen, C.; Ingenbleek, Y. Clin. Chem. Lab. Med., 2002, 40, 1339.

[139] Lasztity, N.; Biro, L.; Nemeth, E.; Pap, A.; Antal, M. Clin. Chem. Lab. Med., 2002, 40, 1320 .

[140] Reimund, J.M.; Arondel, Y.; Escalin, G.; Finck, G.; Baumann, R.; Duclos, B. Dig. Liver Dis., 2005, 37, 424.

[141] Shiga, C.; Ohi, R.; Chiba, T.; Nio, M.; Endo, N.; Mito, S.; Hino, M. Tohoku J. Exp. Med., 1977, 181, 217.

[142] Caregaro, L.; Alberino, F.; Amodio, P.; Merkel, C.; Bolognesi, M.; Angeli, P.; Gatta, A. Am. J. Clin. Nutr., 1996, 63, 602.

[143] Yasmin, M.Y.; Aziz, B.; Nazim, M.; Madhavan. R.K. Malays. J. Pathol., 1993, 15, 147

[144] Merli, M.; Romiti, A.; Riggio, O.; Capocaccia, L. J. Parenter. Enter. Nutr., 1987, 11, S130.

[145] McCullough, A.J.; Tavill, A.S. Semin. Liver Dis., 1991, 11, 265.

[146] Plevak, D.J.; DiCecco, S.R.; Wiesner, R.H.; Porayko, M.K.; Wahlstrom, H.E.; Janzov, D.J.; Hammel, K.D.; O'Keefe, J.D. Mayo Clin. Proc., 1994, 69, 225

[147] Tanaka, A.; Sano, K.; Tanaka, K.; Honda, K.; Uemoto, S.; Takada, Y.; Yamaoka, Y.; Inamoto, T.; Shimahara, Y.; Mori, K. Am. J. Surg., 1993, 166, 32

[148] Gonzalez-Castro, A.; Llorca, J.; Suberviola, B.; Diaz-Reganon, G.; Ordonez, J.; Minambres, E. Transplant. Proc., 2006, 38, 2539.

[149] Cano, N.; Fernandez, J.P.; Lacombe, P.; Lankester, M.; Pascal, S.; Defayolle, M.; Labastie, J.; Saingra, S. Kidney Int., 1987, 32 (Suppl. 22), S178.

[150] Chertow, G.M.; Ackert, K.; Lew, N.L.; Lazarus, J.M.; Lowrie, E.G. Kidney Int., 2000, 58, 2512.

[151] Duggan, A.; Huffman, F.G. J. Ren. Nutr., 1998, 8, 142.

[152] Combe, C.; Chauveau, P.; Laville, M.,; Fouque, D.; Azar, R.; Cano, N.; Canaud, B.; Roth, H.; Leverve, X.; Aparicio, M. and the French Study Group in Dialysis. Am. J. Kidney Dis., 2001, 37, S81.

[153] Avram, M.M.; Sreedhara, R.; Fein, P.; Oo, K.K.; Chattopadhyay, J.; Mittman, N. Am. J. Kidney Dis., 2001, 37 (Suppl. 2), S77.

[154] Holland, D.C.; Meers, C.; Lawlor, M.E.; Lam, M. J. Ren. Nutr., 2001, 11, 129.

[155] Chertow, G.M.; Goldstein-Fuchs, D.J.; Lazarus, J.M.; Kaysen, G.A. Kidney Int., 2005, 68, 2794.

[156] Schelp, F.B.; Migasena, P.; Vudhivai, N.; Boonperm, P.; Supawan, V.; Pongpaew, P.; Harinasuta, C.; Intrapraseet, R.; Tharakul, C. Tropenmed. Parasitol., 1977, 28, 319.

[157] Monnet, D.; Lonsdorfer, A.; Penali, K.; Valero, D.; Doua, F.; Bogui, P.; Yapo, A. Bull. Soc. Pathol. Exot., 1997, 90, 105.

[158] Camacho-Lobato, L.; Borges, D.R. J. Hepatol., 1998, 29, 233

[159] Dao, H.; Delisle, H.; Fournier, P. J. Trop. Pediatr., 1992, 38, 179.

[160] Khan, W.A.; Salam, M.A.; Bennish, M.L. Gut, 1995, 37, 402

[161] Huang, C.M.; Ruddel, M.; Elin, R.J. Clin. Chem., 1988, 34, 1957.

[162] VanItallie, T.B. Metabolism, 2003, 52 (Suppl. 2), 22.

[163] Bonnefoy, M.; Coulon, L.; Bienvenu, J.; Boisson, R.C.; Rys, L. Age Ageing, 1995, 24, 37.

[164] Visser, M.; Pahor, M.; Taaffe, D.R.; Goodpaster, B.H.; Simonsiock, E.M.; Newman, A.B.; Nevitt, M.; Harris, T.B. J. Gerontol. A Biol. Sci. Med. Sci., 2002, 57, M326.

[165] Lehmann, A.B. Age Ageing, 1989, 18, 339. 
[166] Sullivan, D.H.; Patch, G.A.; Walls, R.C.; Lipchitz, D.A. Am. J. Clin. Nutr., 1990, 51, 749 .

[167] Constans, T.; Bacq, Y.; Bréchot, J.F.; Guilmot, J.L.; Choute, P.; Lamisse, F. J. Am. Geriatr. Soc., 1992, 40, 263.

[168] Tamas, F. Jr.; Herrmann, F.; Rapin, C.H. Arch. Gerontol. Geriatr., 1991, 12, 31 .

[169] Patterson, B.M.; Cornell, C.N.; Carbone, B.; Levine, B.; Chapman, D. J. Bone Joint Surg. Am., 1992, 74A, 251.

[170] Rico, H.; Relea, P.; Crespo, R.; Revilla, M.; Villa, L.F.; Arribas, I.; Usabiaga, J. J. Bone Joint Surg. Br., 1995, 77, 148.

[171] Paillaud, E.; Merlier, I.; Dupeyron, C.; Scherman, E.; Poupon, J.; Bories, P.N. Br. J. Nutr., 2004, 92, 861.

[172] Delcourt, C.; Dupuy, A.M.; Carrière, I.; Lacroux, A.; Cristol, J.P. Arch. Ophtalmol., 2005, 123, 225.

[173] Navab, M.; Mallia, A.K.; Kanda, Y.; Goodman, D.S. J. Biol. Chem., 1977, 252, 5100 .

[174] Enrione, E.B.; Ogle, C.; Smith, J.E.; Popp, M.B. Surg. Forum, 1986, 37, 44.

[175] Enrione, E.B.; Ogle, C.; Smith, J.E.; Popp, M.B. J. Surg. Res., 1987, 43, 149.

[176] Bourry, J.; Milano, G.; Caldani, C.; Schneider, M. Ann. Clin. Lab. Sci., 1982, 12, 158.

[177] Ota, D.M.; Frasier, P.; Guevara, J.; Foulkes, M. J. Surg. Oncol., $\mathbf{1 9 8 5}, 29,160$.

[178] Elhasid, R.; Laor, A.; Lischinsky, S.; Postovsky, S.; Weyl Ben Arush, M. Cancer, 1999, 86, 119.

[179] Yu, L.C.; Kuvibidila, S.; Ducos, R.; Warrier, R.P. Med. Pediatr. Oncol., 1994, 22, 73.

[180] Reed, M.D.; Lazarus, H.M.; Herzig, R.H.; Halpin, T.C. Jr.; Gross, S.; Husak, M.P.; Blumer, J.L. Cancer, 1983, 51, 1563.

[181] Milano, G.; Cooper, E.H.; Goligher, J.C.; Giles, G.R.; Neville, A.M. J. Natl. Cancer Inst., 1978, 61, 687.

[182] Suresh, U.R.; Wilkes, S.; Hasleton, P.S. J. Clin. Pathol., 1991, 44, 573.

[183] Mählck, C.G.; Grankvist, K. Gynecol. Obstet. Invest., 1994, 37, 135.

[184] Solomon, M.J.; Smith, M.F.; Dowd, J.B.; Bistrian, B.R.; Blackburn, G.L. J. Urol., 1978, 119, 350.

[185] Geisler, J.P.; Linnemeier, G.C.; Thomas, A.J.; Manahan, K.J. Gynecol. Oncol., 2007, 106, 128.

[186] Ho, S.Y.; Guo, H.R.; Chen, H.H.; Peng, C.J. J. Formos. Med. Assoc., 2003, 102, 544 .

[187] Sann, L.; Bienvenu, F.; Bienvenu, J.; Bourgeois, J.; Bethenod, M. J. Pediatr., 1984, 105, 977.

[188] Férard, G.; Gaudias, J.; Bourguignat, A.; Ingenbleek, Y. Clin. Chem. Lab. Med., 2002, 40, 1334.

[189] Harrisson, S.P. Med. Lab. Sci., 1987, 44, 15.

[190] Avram, M.M.; Fein, P.A.; Paluch, M.M.; Schloth, T.; Chattopadhyay, J. Adv. Perit. Dial., 2005, 21, 154.

[191] Pinilla, J.C.; Hayes, P.; Laverty, W.; Arnold, C.; Laxdal, V. Surgery, 1998, 124, 799 .

[192] Hollinshead, A.C.; Chuang, C.Y.; Cooper, E.H.; Catalona, W.J. Cancer, 1977, 40, 2993.

[193] Charet, J.C.; Watine, J.; Lepretre, A.; Raimbault, C.; Charet, P. Clin. Biochem., 1996, 29, 289.

[194] Ingenbleek, Y.; Carpentier, Y. Internat. J. Vit. Nutr. Res., 1985, 55, 91.

[195] He, Q.Y.; Lau, G.K.; Zhou, Y.; Yuen, S.T.; Lin, M.C.; Kung, H.F.; Chiu, J.F. Proteomics, 2003, 3, 666

[196] Agranoff, D.; Fernandez-Reyes, D.; Papadopoulos, M.C.; Rojas, S.A.; Herbster, M.; Loosemore, A.; Tarelli, E.; Sheldon, J.; Schwenk, A.; Pollok, R.; Rayner, C.F.; Krishna, S. Lancet, 2006, 368,1012 .

[197] Castano, E.M.; Roher, A.E.; Esh, C.L.; Kokjohn, T.A.; Beach, T. Neurol. Res., 2006, 28, 155.

[198] Fung, E.T.; Yip, T.T.; Lomas, L.; Wang, Z.; Yip, C.; Meng, X.Y.; Lin, S; Zhang, F.; Zhang, Z.; Chan, D.W.; Weinberger, S.R. Int. J. Cancer, 2005, 115, 783 .

[199] Larson, E.B. N. Engl. J. Med., 1993, 328, 203.

[200] Román, G. Int. J. Clin. Pract. Suppl., 2001, 120, 9.

[201] Elovaara, I.; Palo, J.; Erkinjuntti, T.; Sulkava, R. Eur. Neurol., 1987, 26, 229.

[202] Lewis, H.; Beher, D; Cookson, N.; Oakley, A.; Piggott, M.; Morris, C.M.; Jaros, E.L.; Perry, R.; Ince, P.; Kenny, R.A.; Ballard, C.G.; Shearman, M.S.; Kalaria, R.N. Neuropathol. Appl. Neurobiol., 2006, 32, 103.
[203] Wikby, A.; Nilsson, B.O.; Forsey, R.; Thompson, J.; Strindhall, J.; Löfgren, S.; Ernerudh, J.; Pawelec, G.; Ferguson, F.; Johansson, B. Mech. Ageing Dev., 2006, 127, 695.

[204] Uchikado, H.; Akiyama, H.; Kondo, H.; Ikeda, K.; Tsuchiya, K.; Kato, M.; Oda, T.; Togo, T.; Iseki, E.; Kosaka, K. Acta Neuropathol. (Berl.), 2004, 107, 341.

[205] Liukkonen, T.; Silvennoinen-Kassinen, S.; Jokelainen, J.; Räsänen, P.; Leinonen, M.; Meyer-Rochow, V.B.; Timonen, M. Biol. Psychiatry, 2006, 60, 825 .

[206] Ikeda, K.; Akiyama, H.; Arai, T.; Oda, T.; Kato, M.; Iseki, E.; Kosaka, K.; Wakabayashi, K.; Takahashi, H. Dement. Geriatr. Cogn. Disord., 1999, 10, 6.

[207] Harris, T.B.; Ferrucci, L.; Tracy, R.P.; Corti, M.C.; Wacholder, S.; Ettinger, W.H.Jr.; Heimovitz, H.; Cohen, H.J.; Wallace, R. Am. J. Med., 1999, 106, 506.

[208] McCaddon, A.; Davies, G.; Hudson, P.; Tandy, S.; Cattell, H. Int J. Geriatr. Psychiatry, 1998, 13, 235.

[209] Clarke, R.; Smith, A.D.; Jobst, K.A.; Refsum, H.; Sutton, L.; Ueland, P.M. Arch. Neurol., 1998, 55, 1449.

[210] Quadri, P.; Fragiacomo, C.; Pezzati, R.; Zanda, E.; Forloni, G.; Tettamanti, M.; Lucca, U. Am. J. Clin. Nutr., 2004, 80, 114.

[211] Welch, G.N.; Loscalzo, J. N. Eng. J. Med., 1998, 338, 1042

[212] Hankey, G.J.; Eikelboom, J.W. Lancet, 1999, 354, 407.

[213] Ingenbleek, Y.; Young, V.R. Nutr. Res. Rev., 2004, 17, 135.

[214] Herbert, J.; Wilcox, J.N.; Pham, K.; Fremeau, R.T.Jr.; Zeviani, M.; Dwork, A.; Soprano, D.R.; Makover, A.; Goodman, D.S.; Zimmerman, E.A.; Roberts, J.L.; Schon, E.A. Neurology, 1986, 36, 900.

[215] Kato, M.; Soprano, D.R.; Makover, A.; Kato, K.; Herbert, J.; Goodman, D.S. Differenciation, 1986, 31, 228.

[216] Weisner, B.; Roethig, H.J. Eur. Neurology, 1983, 22, 96.

[217] Hagen, G.A.; Elliott, W.J. J. Clin. Endocrinol. Metab., 1973, 37 , 415.

[218] Larsen, P.D.; DeLallo, L. Ann. Neurol., 1989, 25, 629.

[219] Schreiber, G.; Aldred, A.R.; Jaworowski, A.; Nilsson, C.; Achen, M.; Segal, M.B. Am. J. Physiol., 1990, 258, R338.

[220] Forterre, S.; Raila, J.; Forterre, F.; Brunnberg, L.; Schweigert, F.J. Vet. J., 2006, 171, 451.

[221] Aldred, A.R.; Brack, C.M.; Schreiber, G. Comp. Biochem. Physiol. B Biochem. Mol. Biol., 1995, 111, 1

[222] Smeland, S.; Bjerknes, T.; Malaba, L.; Eskild, W.; Norum, K.R.; Blomhoff, R. J. Biochem., 1995, 305, 419.

[223] MacDonald, P.N.; Bok, D.; Ong, D.E. Proc. Natl. Acad. Sci. USA, 1990, 87, 4265.

[224] Bernal, J. Vitam. Horm., 2005, 71, 95.

[225] Blomhoff, R.; Blomhoff, H.K. J. Neurobiol., 2006, 66, 606.

[226] Episkopou, V.; Maeda, S.; Nishigushi, S.; Shimada, K.; Gaitanaris, G.A.; Gottesman, M.E.; Robertson, E.J. Proc. Natl. Acad. Sci. USA, 1993, 90, 2375.

[227] Ingenbleek, Y.; Van den Schrieck, H.G.; De Nayer, P.; De Visscher, M. Metabolism, 1975, 24, 633.

[228] van Benekum, A.M.; Wei, S.; Gamble, M.V.; Vogel, S.; Piantedosi, R.; Gottesman, M.; Episkopou, V.; Blaner, W.S. J. Biol. Chem., 2001, 276, 1107 .

[229] György, P. Fed. Proc., 1968, 27, 949.

[230] Kim, C.I.; Leo, M.A.; Lieber, C.S. Arch. Biochem. Biophys., 1992 $294,388$.

[231] Goodman, A.B.; Pardee, A.B. Proc. Natl. Acad. Sci. USA, 2003, 100, 2901.

[232] Napoli, J.L. Biochim. Biophys. Acta, 1999, 1440, 139.

[233] Fex, G.A.; Larsson, K.; Nilsson-Ehle, I. J. Nutr. Biochem., 1996, 7, 162.

[234] Muindi, J.R.; Frankel, S.R.; Huselton, C.; DeGrazia, F.; Garland, W.A.; Young, C.W.; Warrell, R.P. Jr. Cancer Res., 1992, 52, 2138.

[235] Sandman, P.O.; Adolfsson, R.; Nygren, C.; Hallmans, G.; Windblad, B. J. Am. Geriatr. Soc. 1987, 35, 31

[236] Wagner, E.; Luo, T.; Dräger, U.C. Cereb. Cortex, 2002, 12, 1244.

[237] Thompson Haskell, G.; Maynard, T.M.; Shatzmiller, R.A.; LaMantia, A.S. J. Comp. Neurol., 2002, 452, 228.

[238] McCaffery, P.; Zhang, J.; Crandall, J.E. J. Neurobiol., 2006, 66, 780.

[239] Corcoran, J.P.; So, P.L.; Maden, M. Eur. J. Neurosci., 2004, 20 , 896.

[240] Etchamendy, N.; Enderlin, V.; Marighetto, A.; Vouimba, R.M.; Pallet, V.; Jaffard, R.; Higueret, P.J. J. Neurosci., 2001, 21, 6423. 
[241] Husson, M.; Enderlin, V.; Delacourte, A.; Ghenimi, N.; Alfos, S.; Pallet, V.; Higueret, P. Neurobiol. Dis., 2006, 23, 1.

[242] Ono, K.; Yoshiike, Y.; Takashima, A.; Hasegawa, K.; Naiki, H.; Yamada, M. Exp. Neurol., 2004, 189, 380.

[243] Brouillette, J.; Quirion, R. Neurobiol. Aging, 2007 (in press).

[244] Schwarzman, A.L.; Gregori, L.; Vitek, M.P.; Lyubski, S.; Strittmatter, W.J.; Enghilde, J.J.; Bhasin, R.; Silverman, J.; Weisgraber, K.H.; Coyle, P.K. Proc. Natl. Acad. Sci. USA, 1994, 91, 8368.

[245] Ingenbleek, Y.; Hardillier, E.; Jung, L. Nutrition, 2002, $18,40$.

[246] Finkelstein, J.D.; Martin, J.J. J. Biol. Chem., 1984, 259, 9508.

[247] Okawa, H.; Morita, T.; Sugiyama, K. Biosci. Biotechnol. Biochem., 2006, 70, 3050

[248] Fuller, M.F.; McWilliam, R.; Wang, T.C.; Giles, L.R. Br. J. Nutr., 1989, 62, 255.
[249] Ingenbleek, Y. J. Nutr., 2006, 136, S1641.

[250] Riisøen, H. Acta Neurol. Scand., 1988, 78, 455

[251] Ledue, T.B.; Rifai, N.; Irish, G.R.; Silverman, L.M. Clin. Chem., 1987, 33, 1260.

[252] Bernstein, L.H. Nutrition, 1995, 11, S205

[253] Mears, E. Nutrition, 1996, 12, 479.

[254] Potter, M.A.; Luxton, G. Clin. Invest. Med., 1999, 22, 44

[255] Brugler, L.; Stankovic, A.; Bernstein, L.; Scott, F.; O'SullivanMaillet, J. Clin. Chem. Lab. Med., 2002, 40, 1360.

[256] Reilly, J.J.; Hull, S.F.; Albert, N.; Walker, A.; Bringerdener, S. J. Parenter. Enter. Nutr., 1988, 12, 371.

[257] Cano, N.J.; Fouque, D.; Roth, H.; Aparicio, M.; Azar, R.; Canaud, B.; Chauveau, P.; Combe, C.; Laville, M.; Leverve, X.M. J. Am. Soc. Nephrol., 2007, 18, 2583.

(C) Yves and Jacques; Licensee Bentham Open.

This is an open access article distributed under the terms of the Creative Commons Attribution License (http://creativecommons.org/licenses/by/2.5/), which permits unrestrictive use, distribution, and reproduction in any medium, provided the original work is properly cited. 